\title{
OCENA JAKOŚCI TABORU TRANSPORTU PUBLICZNEGO NA PRZYKŁADZIE MIASTA CZĘSTOCHOWY
}

\author{
Monika Strzelczyk \\ Politechnika Częstochowska \\ Wydział Zarządzania
}

\begin{abstract}
Streszczenie: $\mathrm{W}$ artykule zaprezentowano podstawowe zagadnienia dotyczące miejskiego transportu pasażerskiego i organizacji regularnego przewozu osób w publicznym transporcie zbiorowym. Głównym celem artykułu jest dokonanie oceny jakości taboru komunikacji miejskiej w Częstochowie. Wydanie opinii na ten temat było możliwe dzięki przeprowadzonym badaniom własnym. Na początku scharakteryzowano aktualnie wykorzystywany tabor komunikacji miejskiej, uwzględniając liczbę pojazdów, markę, typ i rok produkcji lub datę zakupu. Wykonanie tej analizy było możliwe dzięki zastosowaniu jednej z metod badań jakościowych, a mianowicie metody Desk Research. Z kolei wykorzystana metoda badań ilościowych (metoda ankietowa) pozwoliła na zebranie wśród mieszkańców miasta opinii na temat nurtujących autorkę kwestii, tj. stanu pojazdów komunikacji miejskiej (autobusów, tramwajów), dostosowania ich do potrzeb osób niepełnosprawnych, czystości wewnątrz pojazdów czy zapewnienia bezpieczeństwa usługobiorcom. Wyniki przeprowadzonych badań pozwoliły na wskazanie priorytetowych działań, które należałoby podjąć w celu podniesienia jakości w tym obszarze.
\end{abstract}

Słowa kluczowe: komunikacja miejska, linia komunikacyjna, publiczny transport zbiorowy, sieć komunikacyjna, tabor transportu publicznego

DOI: $10.17512 /$ znpcz.2017.4.2.06

\section{Wprowadzenie}

Transport stanowi jeden $\mathrm{z}$ podstawowych działów gospodarki narodowej. $\mathrm{Z}$ jednej strony warunkuje on sprawną realizację procesów zaopatrzeniowych, produkcyjnych i dystrybucyjnych w przedsiębiorstwach produkcyjnych, usługowych i/lub handlowych, tym samym zaspokajając potrzeby transportowe przedsiębiorstw (Krysiuk 2016, s. 48). Z drugiej strony transport pozwala na zaspokajanie potrzeb transportowych społeczeństwa. Podstawowym źródłem powstania tych potrzeb jest chęć przemieszczania się ludności w celach pracowniczych czy edukacyjnych. $\mathrm{Na}$ częstotliwość tych przemieszczeń ma wpływ wiele czynników. Należą do nich: struktura demograficzna społeczeństwa, liczba podmiotów prowadzących działalność handlową i usługową, instytucji zajmujących się działalnością edukacyjną, naukowo-badawczą itp. na określonym obszarze. Wśród potrzeb transportowych ludności należy również wyszczególnić te, które są zaspokajane w wyniku realizacji przewozów w celach zakupowych, kulturowych, wypoczynkowych, rekreacyjno-wypoczynkowych czy zdrowotnych. W tym przypadku na częstotliwość i zasięg realizowanych przemieszczeń ma wpływ przede wszystkim sytuacja ekonomiczna czy stan zdrowia społeczeństwa. 
Przewozy osób w miastach są realizowane przy wykorzystaniu środków transportu indywidualnego i/lub pojazdów transportu publicznego. Społeczeństwo ma pełną dowolność w wyborze rodzaju transportu. Obecnie podstawowym zadaniem jednostek samorządów terytorialnych jest kształtowanie zachowań komunikacyjnych ludności. W ostatnim czasie dostrzeżono bowiem dużą szansę na zapewnienie zrównoważonego rozwoju transportu ${ }^{1}$, dzięki zwiększeniu stopnia wykorzystania komunikacji miejskiej podczas przejazdów. Wysoka jakość oferowanych usług przewozowych może w korzystny sposób wpływać na wzrost zainteresowania wśród społeczeństwa transportem publicznym. Zgodnie z powyższym celem artykułu jest dokonanie oceny jakości taboru komunikacji miejskiej w Częstochowie. Pozwoli to na unaocznienie braków w tym zakresie i zdefiniowanie działań koniecznych do wdrożenia, pozwalających na kształtowanie zachowań komunikacyjnych społeczeństwa $\mathrm{i}$ - co jest $\mathrm{z}$ tym związane - zachowanie ładu społecznego, ekonomicznego i środowiskowego w mieście.

\section{Transport w mieście}

Transport jest jednym z działów gospodarki narodowej, determinującym rozwój lokalny (Kabus, Nowakowska-Grunt 2016, s. 40; Grondys, Kott, Sukiennik 2017, s. 245) pod względem gospodarczo-społecznym (Skowron-Grabowska 2009, s. 12). Definicja transportu została podana przez wielu autorów. Klasyczne podejście do pojęcia transportu zostało zaprezentowane przez I. Tarskiego, który stwierdził, że jest on ,procesem technologicznym wszelkiego przenoszenia na odległość, czyli przemieszczania osób, przedmiotów lub energii” (Tarski 1993, s. 11). Można zatem stwierdzić, że proces transportu ma na celu przemieszczanie osób i różnego typu obiektów w czasie i przestrzeni (Krawczyk 2011, s. 273; Urbanyi-Popiołek (red.) 2013, s. 9) przy wykorzystaniu taboru (Stajniak 2006, s. 83; Kramarz, Kramarz, Bendkowski 2010, s. 113) odpowiedniego dla poszczególnych gałęzi transportu.

Transport realizowany w mieście to przede wszystkim przewóz osób (transport pasażerski) i ładunków (transport towarowy). W ostatnim czasie wzrosła rola obu rodzajów transportu. Spowodowało to zwiększenie zainteresowania samorządów lokalnych zagadnieniami logistyki miejskiej czy logistyki miasta, które zostały opisane przez wielu zagranicznych i polskich autorów (Taniguchi, Thompson, Yamada 1999; Taniguchi, Thompson, Yamada 2013, s. 2; Gołembska 2001; Grzelec, Wyszomirski 2002, s. 24; Rzeczyński 2002, s. 10-11; Rzeczyński 2004, s. 13-14; Krawczyk 2004; Szołtysek 2005, s. 105; Moterski 2008, s. 89; Witkowski 2014, s. 13-14). Według J. Szołtyska zadaniem logistyki miasta jest zarządzanie przepływem materialnym w mieście, przepływem pasażerów, a także wymianą informacji pomiędzy uczestnikami miejskiego systemu logistycznego (Szołtysek 2016, s. 45). Można zatem wywnioskować, że najważniejszym zadaniem stawianym

\footnotetext{
${ }^{1}$ Według Komisji Europejskiej zrównoważony rozwój transportu to rozwój zapewniający dostępność celów komunikacyjnych zarówno dla obecnego, jak i następnych pokoleń (Janecki, Krawiec, Sierpiński 2010, s. 111).
} 
przed logistyką miejską / logistyką miasta jest usprawnienie realizacji procesów transportowych. Bez wątpienia sprawne przemieszczanie osób i ładunków determinuje atrakcyjność krajów, regionów i miast (Nowakowska-Grunt, Chłąd 2015, s. 128).

Nie umniejszając roli przewozów towarowych, uwzględniając tematykę artykułu, w dalszej części opracowania rozpatrywane będą jedynie zagadnienia dotyczące publicznego transportu zbiorowego. Jak spostrzegli J. Stokłosa, J. Rymarz i A. Niewczas, podejście logistyczne do zarządzania transportem pasażerskim w mieście to połączenie poszczególnych podsystemów transportu w jedną całość (jeden system). Dzięki temu możliwe jest zapewnienie usług transportowych na wysokim poziomie (Stokłosa, Rymarz, Niewczas 2012, s. 152), szczególnie teraz, kiedy oczekiwania społeczne wobec samorządów lokalnych wciąż rosną (Chłąd, Jaroszyński 2015, s. 12). M. Kiciński i P. Stasiak potwierdzili, że „transport miejski i transport podmiejski należą do najważniejszych podsystemów determinujących prawidłowe funkcjonowanie obszarów zurbanizowanych oraz jakość życia ich mieszkańców" (Kiciński, Stasiak 2013, s. 555). Zdaniem autorki zarządzanie transportem publicznym jest więc zadaniem niezwykle istotnym, za którego wykonanie jest odpowiedzialny organizator publicznego transportu zbiorowego. Podstawowe pojęcia związane $\mathrm{z}$ organizacją transportu publicznego w miastach zostały zaprezentowane $\mathrm{w}$ dalszej części artykułu.

\section{Organizacja transportu zbiorowego w mieście}

Głównym zadaniem organów zarządzających transportem w mieście jest dążenie do zapewnienia właściwej organizacji transportu publicznego w obrębie granic administracyjnych miast oraz transportu integrującego system transportu pasażerskiego $\mathrm{w}$ mieście z systemem transportu na obszarach sąsiadujących (np. gmin, miast). Transport publiczny stanowi jeden $\mathrm{z}$ ważniejszych elementów systemu transportowego miasta. Podstawowym aktem prawnym opisującym proces organizowania i funkcjonowania regularnego przewozu osób w publicznym transporcie zbiorowym w Polsce jest Ustawa z dnia 16 grudnia 2010 r. o publicznym transporcie zbiorowym. Przepisy ustawy stosuje się z uwzględnieniem regulacji zawartych w rozporządzeniach Parlamentu Europejskiego i Rady. Według art. 4 ustawy transport zbiorowy jest definiowany jako powszechnie dostępny regularny przewóz osób wykonywany w określonych odstępach czasu i po określonej linii komunikacyjnej, liniach komunikacyjnych lub sieci komunikacyjnej (Ustawa z dnia 16 grudnia 2010 r. ..., art. 4 ust. 1 pkt 14). W dalszej kolejności zasadnym staje się wyjaśnienie pojęć pojawiających się $\mathrm{w}$ definicji transportu publicznego. Zatem linią komunikacyjną określane jest połączenie komunikacyjne wraz $\mathrm{z}$ oznaczonymi miejscami do wsiadania i wysiadania pasażerów na liniach komunikacyjnych, po których odbywa się publiczny transport zbiorowy (Ustawa $\mathrm{z}$ dnia 16 grudnia 2010 r. ..., art. 4 ust. 1 pkt 5). Z kolei sieć komunikacyjną według ustawy stanowi układ linii komunikacyjnych obejmujących obszar działania organizatora publiczne -go transportu zbiorowego lub część tego obszaru (Ustawa z dnia 16 grudnia 2010 r. ..., ust. 1 pkt 16). 
Za zarządzanie transportem publicznym odpowiada organizator, którym jest właściwa jednostka samorządu terytorialnego albo minister właściwy do spraw transportu, zapewniający funkcjonowanie publicznego transportu zbiorowego na danym obszarze (Ustawa z dnia 16 grudnia 2010 r. ..., ust. 1 pkt 9). Transport publiczny w miastach może być realizowany przez operatora publicznego transportu zbiorowego lub przewoźnika. Operator publicznego transportu zbiorowego świadczy usługi na podstawie umowy. Umowa ta jest zawierana pomiędzy organizatorem publicznego transportu zbiorowego a operatorem. Operator na mocy umowy otrzymuje prawo i jest zobowiązany do realizowania określonych usług związanych z wykonywaniem przewozu o charakterze użyteczności publicznej. Oznacza to, że usługi świadczone przez operatora publicznego transportu zbiorowego powinny być powszechnie dostępne i służyć zaspokojeniu potrzeb przewozowych społeczności na danym obszarze (Ustawa z dnia 16 grudnia 2010 r. ..., ust. 1 pkt 8 i 12). Przewoźnikiem jest natomiast przedsiębiorca uprawniony do prowadzenia działalności gospodarczej w zakresie przewozu osób na podstawie potwierdzenia zgłoszenia przewozu (transport drogowy) lub na podstawie decyzji o przyznaniu otwartego dostępu (transport kolejowy) (Ustawa z dnia 16 grudnia 2010 r. ..., ust. 1 pkt 11).

W Częstochowie, podobnie jak w każdym innym mieście, powołany został organizator i operator publicznego transportu zbiorowego oraz wytyczone zostały linie tworzące układ komunikacyjny. Linie te obsługiwane są przez środki transportu drogowego i szynowego. Informacje na ten temat zaprezentowane zostały w dalszej części artykułu.

\section{Układ komunikacyjny w Częstochowie}

Rolę organizatora publicznego transportu zbiorowego w mieście pełni Miejski Zarząd Dróg i Transportu (w skrócie MZDiT) w Częstochowie (Urząd Miasta Częstochowy 2013, s. 37). Operatorem publicznego transportu zbiorowego jest Miejskie Przedsiębiorstwo Komunikacyjne (MPK) w Częstochowie Sp. zo.o. Uwzględniając formę organizacyjno-prawną, należy zauważyć, że przedsiębiorstwo należy do grupy spółek prawa handlowego, którego właścicielem posiadającym 100\% udziałów w spółce, jest miasto Częstochowa. 


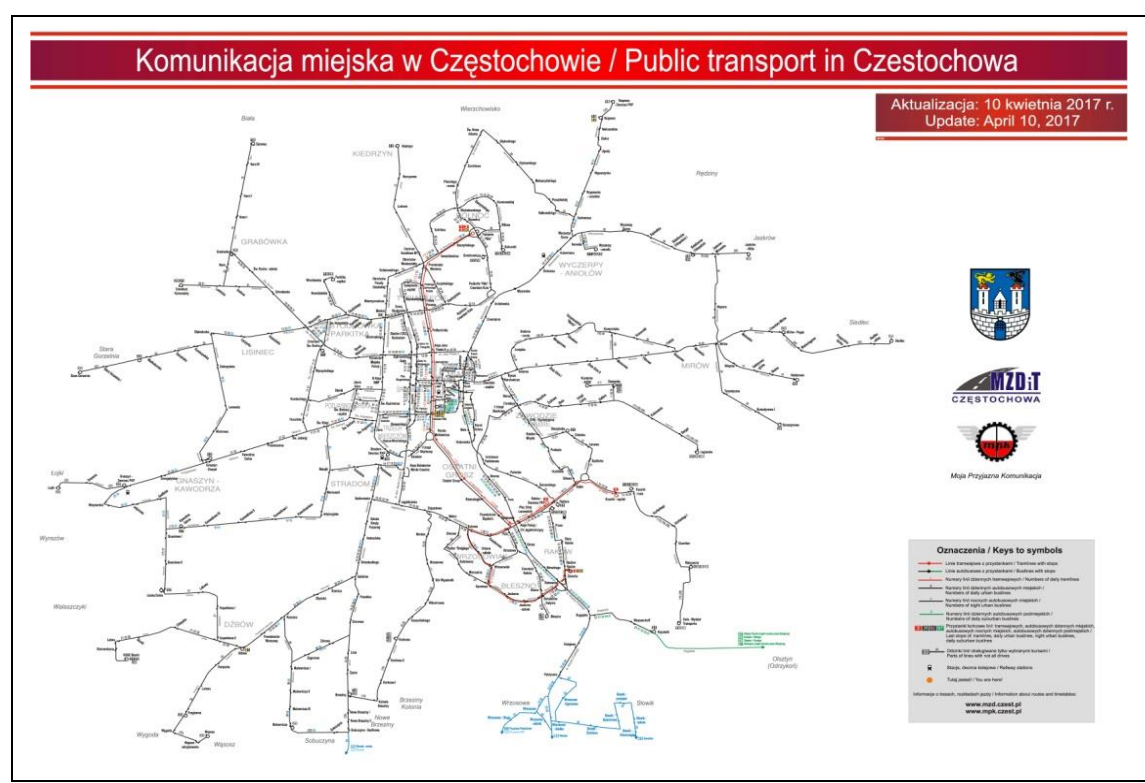

Rysunek 1. Mapka układu komunikacyjnego w Częstochowie i sąsiadujących gminach

Źródło: (http://mzd.czest.pl/images/rozklady/mapka_si_kom.pdf)

Strefa sieci komunikacyjnej obsługiwanej przez operatora publicznego transportu zbiorowego w Częstochowie obejmuje obszar zlokalizowany w granicach administracyjnych miasta i 5 okolicznych gminach (Rysunek 1). Sieć komunikacji w mieście zawiera 43 trasy tramwajowe i autobusowe (Rysunek 2).

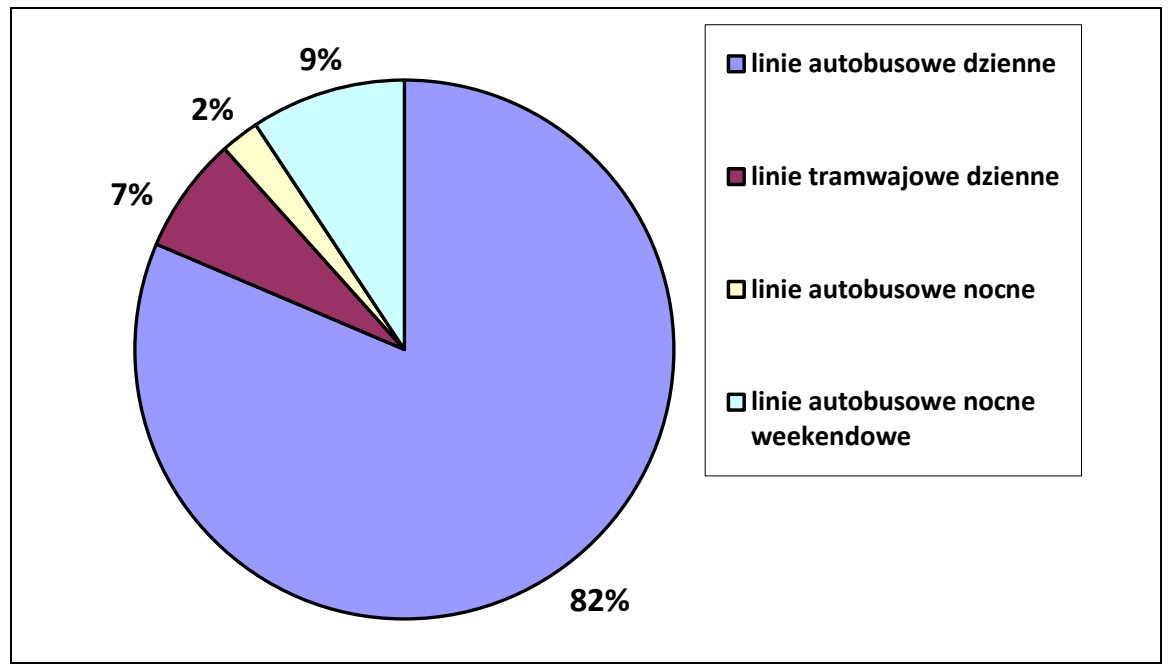

Rysunek 2. Struktura linii autobusowych i tramwajowych w Częstochowie

Źródło: Opracowanie na podstawie (http://mzd.czest.pl/publiczny-transport-zbiorowy/rozkladyjazdy) 
74\% wszystkich linii stanowią linie autobusowe miejskie. Wśród nich wyróżnić można:

27 linii autobusowych miejskich dziennych: 10, 11, 12, 13, 14, 15, 16, 17, 18, $19,20,21,22,23,24,25,26,28,29,30,31,32,33,35,36,38$ i 92 ;

1 linia autobusowa miejska nocna: 80 ;

4 linie autobusowe miejskie nocne weekendowe: 81, 82, 83 i 84.

Wśród gmin, na których terenie świadczy usługi MPK w Częstochowie - $\quad$ Sp. z o.o., wyróżnia się gminy: Poczesna, Olsztyn, Mstów, Konopiska i Blachownia. Na wskazanym obszarze wytyczonych zostało 8 linii autobusowych podmiej-

- $\quad$ skich, co stanowi 19\% ogółu linii komunikacyjnych.

Tabela 1. Linie komunikacji miejskiej i podmiejskiej integrujące miasto Częstochowę z sąsiadującymi gminami

\begin{tabular}{|l|c|c|}
\cline { 2 - 3 } \multicolumn{1}{|l}{} & $\begin{array}{c}\text { Linia/linie } \\
\text { miejskie }\end{array}$ & $\begin{array}{c}\text { Linia/linie } \\
\text { podmiejskie }\end{array}$ \\
\hline Gmina Olsztyn & $\mathrm{X}$ \\
\hline linie: $57,58,59,67$ & - & $\mathrm{X}$ \\
\hline Gmina Poczesna & - \\
\hline linie: $53,65,68,69$ & - & - \\
\hline linia: 25 & $\mathrm{X}$ & - \\
\hline Gmina Blachownia & $\mathrm{X}$ & - \\
\hline linie: 22,32 & $\mathrm{X}$ & \\
\hline Gmina Mstów & & \\
\hline linie: 26,30 & $\mathrm{X}$ & \\
\hline Gmina Konopiska & & \\
\hline linia: 30 & & \\
\hline
\end{tabular}

Źródło: Opracowanie na podstawie (http://mzd.czest.pl/publiczny-transport-zbiorowy/rozkladyjazdy)

Linie łączące miasto z sąsiadującymi gminami przybierają charakter linii autobusowych podmiejskich (gmina Olsztyn, Poczesna) lub stanowią przedłużenie kursów linii miejskich (gmina Poczesna, Blachownia, Mstów, Konopiska) (Tabela 1). Na dzień dzisiejszy kursy nocne pomiędzy Częstochową a sąsiadującymi gminami nie są realizowane. 
Linie tramwajowe stanowią 7\% ogółu linii komunikacyjnych w Częstochowie. Przewozy pasażerskie tramwajem są realizowane przez 3 linie dzienne: 1, 2 i 3. Aktualnie w mieście nie funkcjonuje żadna linia tramwajowa nocna i nocna weekendowa. Sytuacja ta prawdopodobnie zmieni się po 1 maja 2017 r., kiedy do użytku zostanie przywrócona ${ }^{2}$ obsługa komunikacyjna tramwajami w dzielnicy Północ.

\section{Środki transportu zbiorowego w Częstochowie}

Transport publiczny w Częstochowie realizowany jest liniami autobusowymi i tramwajowymi za pomocą pojazdów wchodzących w skład taboru transportu publicznego.

\section{Autobusy komunikacji miejskiej}

Według danych udostępnionych na stronie internetowej Miejskiego Przedsiębiorstwa Komunikacyjnego w Częstochowie linie autobusowe dzienne i nocne są obsługiwane przez 146 pojazdów. Niemniej jednak w części opracowania, w której wyszczególnione zostały wszystkie marki i typy autobusów realizujących przewozy, ich liczba wyniosła aż 219 (Tabela 2). Może to wynikać z faktu nieuwzględnienia we wcześniejszych szacunkach pojazdów niedawno zakupionych.

Tabela 2. Wykaz liniowego taboru autobusowego MPK Sp. z o.o.

\begin{tabular}{|l|c|c|c|}
\hline \multicolumn{1}{|c|}{ Marka } & Typ & $\begin{array}{c}\text { Liczba pojazdów } \\
\text { [szt.] }\end{array}$ & Data produkcji \\
\hline Ikarus & 280 & 33 & $1982-1997$ \\
\hline MAN & NG 272 & 2 & 1991 \\
\hline Ikarus & 435 & 1 & 1993 \\
\hline MAN & NL 202 & 6 & $1993-1994$ \\
\hline Ikarus & 415 & 7 & 1995 \\
\hline Ikarus & 412 & 1 & 1997 \\
\hline MAN & NL 222 & 8 & $2000-2001$ \\
\hline MAN & A78 & 5 & 2006 \\
\hline Solaris & O530 Citaro & 9 & 2002 \\
\hline Mercedes-Benz & O345G Conecto & 35 & $2006-2010$ \\
\hline Mercedes-Benz & O530 Citaro G & 8 & 2006 \\
\hline Mercedes-Benz & & 11 & $2009-2010$ \\
\hline
\end{tabular}

\footnotetext{
${ }^{2}$ Komunikacja tramwajowa została zawieszona wiosną 2016 roku na odcinku od Promenady Niemena do ul. Fieldorfa-Nila ze względu na konieczność wykonania prac przy torowisku tramwajowym w rejonie tunelu pod aleją Wyzwolenia.
} 


\begin{tabular}{|c|c|c|c|}
\hline Marka & Тур & $\begin{array}{c}\text { Liczba pojazdów } \\
\text { [szt.] }\end{array}$ & Data produkcji \\
\hline Solaris & Urbino 12 III generacja & 10 & 2014 \\
\hline Solbus & SM12 HL Hybryda & 25 & 2015 \\
\hline Solbus & SM18 HL Hybryda & 15 & 2015 \\
\hline Solbus & SM12 DC Euro6 & 3 & 2016 \\
\hline Solaris & $\begin{array}{c}\text { Urbino } 12 \text { IV generacja } \\
\text { Euro6 }\end{array}$ & 40 & 2017 \\
\hline & Suma & 219 & \\
\hline
\end{tabular}

Źródło: (http://www.mpk.czest.pl/page/o-firmie/tabor; Urząd Miasta Częstochowy 2013, s. 86-89)

Najstarszy liniowy autobus, Ikarus 280.02 , został wprowadzony do eksploatacji w Częstochowie 14 lipca 1982 r. Jest on oznaczony numerem inwentarzowym 288. Autobus ten należał wtedy do zbioru najstarszych pojazdów w Polsce. W 2013 roku średnia wieku autobusów Miejskiego Przedsiębiorstwa Komunikacyjnego wynosiła 12,7 lat. Oznaczało to, że większość środków transportu w tamtym okresie była wyeksploatowana i przestarzała. W celu poprawy trudnej sytuacji taboru komunikacji miejskiej w sierpniu 2013 roku sprowadzono do Częstochowy autobusy pojedyncze niskopodłogowe z rynku wtórnego w Szwecji (Urząd Miasta Częstochowy 2013, s. 90).

Kolejne lata przyniosły dalszą poprawę w tym obszarze. W okresie od 2014 do 2017 roku zakupionych zostało ponad 90 nowoczesnych autobusów. Ostatnia inwestycja zrealizowana w 2017 roku dotyczyła zakupu 40 autobusów Solaris Urbino 12 IV generacji. Pojazdy te zostały wyposażone w klimatyzację, kamery monitoringu, ładowarki USB, bezprzewodowy Internet LTE, biletomaty, kasowniki dwufunkcyjne. Za zakupione pojazdy MPK Częstochowa zapłaciło ponad $45 \mathrm{mln}$ zł. Aż 85\% tej kwoty zostało pokryte ze śląskiego Regionalnego Programu Operacyjnego w ramach projektu „Przyjazna Komunikacja” (http://silesiainfotransport. $\mathrm{pl} /$...). Nowo zakupione autobusy zastąpiły wysłużone pojazdy (m.in. Ikarusy). Bez wątpienia inwestycja ta podniesie standard świadczonych usług przewozowych oraz wpłynie na poprawę komfortu, wygody i bezpieczeństwa przewożonych pasażerów.

\section{Środki transportu innego szynowego w Częstochowie}

Środkami transportu innego szynowego w mieście są tramwaje. Na tabor Miejskiego Przedsiębiorstwa Komunikacyjnego w Częstochowie Sp. z o.o. składa się 55 tramwajów (Tabela 3). 
Tabela 3. Wykaz liniowego taboru tramwajowego MPK Sp. z o.o.

\begin{tabular}{|r|c|c|}
\hline \multicolumn{1}{|c|}{ Typ } & $\begin{array}{c}\text { Liczba } \\
\text { pojazdów } \\
\text { [szt.] }\end{array}$ & Data zakupu \\
\hline Tramwaj typu 105 Na & 48 & $1975-1990$ \\
\hline Tramwaj typu 129 Nb (TWIST) & 7 & 2012 \\
\hline Suma & $\mathbf{5 5}$ & \multicolumn{1}{|c}{} \\
\cline { 1 - 2 } & &
\end{tabular}

Źródło: (http://www.mpk.czest.pl/page/o-firmie/tabor)

Liczba pojazdów jest wystarczająca do zapewnienia sprawnego funkcjonowania linii tramwajowych. Średni czas oczekiwania w dni robocze od września do czerwca na przyjazd tramwaju w kierunku Promenady Niemena na linii nr 1 wynosi 18 minut, linii nr $2-30$ minut oraz na linii nr 3 - ok. 13 minut. Należy jednak podkreślić, że kursy tramwajów poszczególnych linii uzupełniają się. Powoduje to, że w godzinach szczytu komunikacyjnego na odcinku wspólnym linii średni czas oczekiwania pasażerów na przejazd jest relatywnie niższy.

\section{Jakość taboru komunikacji miejskiej w Częstochowie}

W lutym 2016 roku przeprowadzone zostało badanie własne. Analizując zgromadzone dane pierwotne, autorka dokonała m.in. oceny jakości pojazdów realizujących publiczne przewozy pasażerskie w Częstochowie.

\section{Metodologia badań}

W artykule metodę badawczą stanowiła metoda sondażu diagnostycznego, natomiast narzędzie - kwestionariusz ankiety. Dobór próby badawczej był losowy. Biorąc pod uwagę liczbę mieszkańców, przy założeniu wielkości frakcji i błędu maksymalnego, oszacowana została wielkość próby badawczej. W rezultacie 384 ankiety zostały uzupełnione przez częstochowian. Badanie zostało przeprowadzone przez ankieterów bezpośrednio i poddano mu grupę mieszkańców, którzy znaleźli się $\mathrm{w}$ danym czasie $\mathrm{w}$ strategicznych punktach miasta. Tymi punktami były m.in. centrum miasta, okolice dworców PKP i PKS, przystanków tramwajowych, galerii handlowych (np. Galerii Jurajskiej). Średnia wieku przebadanych częstochowian wyniosła 35 lat. Najmłodszy respondent miał 15 lat, najstarszy - 88 lat. Odchylenie standardowe wieku ukształtowało się na poziomie 17,54 lat. W skład próby badawczej wchodziło 57,29\% kobiet i 42,71\% mężczyzn.

\section{Hipotezy badawcze}

Głównym celem artykułu jest dokonanie oceny jakości taboru komunikacji miejskiej w Częstochowie. Dokonanie tej oceny pozwoli na realizację drugiego celu. Jest nim wskazanie priorytetowych działań, które należałoby wdrożyć 
w mieście, aby zwiększyć jakość w tym obszarze. Uwzględniając wyszczególnione cele, autorka zdefiniowała trzy hipotezy badawcze, tj.:

Hipoteza 1. Osoby korzystające $\mathrm{z}$ usług transportu zbiorowego w Częstochowie oceniają jakość autobusów miejskich i tramwajów na poziomie dobrym (średnia ważona ocen wynosi 4).

Hipoteza 2. Użytkownicy infrastruktury komunikacji miejskiej lepiej oceniają jakość autobusów miejskich niż tramwajów.

Hipoteza 3. Utrzymanie w czystości autobusów i tramwajów pozwoliłoby wznacznym stopniu zwiększyć jakość taboru komunikacji miejskiej.

Hipotezy badawcze zostały zweryfikowane dzięki wynikom przeprowadzonych badań własnych, które zostały zaprezentowane w kolejnej części opracowania.

\section{Ocena jakości autobusów miejskich i tramwajów w Częstochowie - wyniki badań własnych}

Respondenci oceniali jakość taboru komunikacji miejskiej, mając na uwadze następujące punkty:

- stan techniczny środków transportowych;

- czystość wewnątrz pojazdów;

- dostosowanie autobusów i tramwajów do potrzeb osób niepełnosprawnych;

- bezpieczeństwo podróżnych wewnątrz środka transportowego.

Dokonując oceny poszczególnych elementów determinujących postrzeganie jakości taboru transportu publicznego, ankietowani mieli do wyboru sześć stwierdzeń. Mogli oni zaznaczyć takie odpowiedzi jak: „bardzo słabo”, „słabo”, „średnio”, „dobrze”, „bardzo dobrze”. Zaznaczonym odpowiedziom zostały przy-porządkowane oceny liczbowe. Były nimi kolejno noty od 1 do 5. Jedną z możliwych odpowiedzi było zaznaczenie stwierdzenia „nie mam zdania”, jednak odpowiedzi te nie były uwzględniane $\mathrm{w}$ trakcie wyznaczania średniej arytmetycznej wszystkich ocen. Na uwagę zasługuje fakt, że oceny mogli dokonać jedynie ci respondenci, którzy z różną częstotliwością (tzn. bardzo często, często, rzadko lub bardzo rzadko) korzystają z komunikacji miejskiej.

Wyniki przeprowadzonych badań zostały zebrane i zaprezentowane w Tabeli 4. Największy odsetek ankietowanych kobiet i mężczyzn zaznaczył w większości przypadków odpowiedź „dobrze”. Jedynie zdecydowana większość kobiet zaznaczyła odpowiedź „słabo” podczas oceny przystosowania tramwajów do potrzeb osób niepełnosprawnych. W tym przypadku również największa liczba mężczyzn zaznaczyła stwierdzenie ,średnio”. 
Tabela 4. Ocena poszczególnych aspektów wpływających na postrzeganie jakości taboru transportu publicznego w mieście Częstochowie

\begin{tabular}{|c|c|c|c|c|}
\hline & \multicolumn{2}{|c|}{ Autobus } & \multicolumn{2}{|c|}{ Tramwaj } \\
\hline & kobiety & mężczyźni & kobiety & mężczyźni \\
\hline \multirow{2}{*}{ Stan techniczny pojazdów } & 3,92 & 4,02 & 3,83 & 3,88 \\
\hline & \multicolumn{2}{|c|}{ średnia ocen: 3,97 } & \multicolumn{2}{|c|}{ średnia ocen: $\mathbf{3 , 8 5}$} \\
\hline \multirow{2}{*}{ Czystość wewnątrz pojazdów } & 3,46 & 3,56 & 3,50 & 3,34 \\
\hline & \multicolumn{2}{|c|}{ średnia ocen: $\mathbf{3 , 5 1}$} & \multicolumn{2}{|c|}{ średnia ocen: 3,42} \\
\hline \multirow{2}{*}{$\begin{array}{l}\text { Dostosowanie pojazdów } \\
\text { do potrzeb osób } \\
\text { niepełnosprawnych }\end{array}$} & 3,76 & 3,92 & 2,91 & 3,01 \\
\hline & \multicolumn{2}{|c|}{ średnia ocen: 3,84} & \multicolumn{2}{|c|}{ średnia ocen: 2,96} \\
\hline \multirow{2}{*}{$\begin{array}{l}\text { Bezpieczeństwo podróżnych } \\
\text { wewnątrz pojazdu }\end{array}$} & 3,66 & 3,62 & 3,74 & 3,64 \\
\hline & \multicolumn{2}{|c|}{ średnia ocen: 3,64} & \multicolumn{2}{|c|}{ średnia ocen: 3,69} \\
\hline Średnia wszystkich ocen & \multicolumn{2}{|c|}{3,74} & \multicolumn{2}{|c|}{3,48} \\
\hline
\end{tabular}

Źródło: Opracowanie własne na podstawie przeprowadzonych badań

Stan techniczny autobusów, czystość ich wnętrza, stopień adaptacji autobusów do potrzeb osób niepełnosprawnych, a także poczucie bezpieczeństwa podróżnych wewnątrz pojazdu zostały ocenione przez 182 kobiety i 107 mężczyzn. Stan czystości, przystosowanie tramwajów do potrzeb osób niepełnosprawnych, jak również bezpieczeństwo podróżnych oceniło 113 kobiet i 59 mężczyzn. Na uwagę zasługuje fakt, że kolejno 112 i 58 respondentów odniosło się do stanu technicznego środków transportu szynowego. Oznacza to, że zarówno jedna kobieta, jak i jeden mężczyzna nie dokonali oceny w tym zakresie.

Według ankietowanych wyższa średnia została zanotowana podczas dokonania oceny jakości autobusów miejskich (Tabela 4). Biorąc pod uwagę wyliczone średnie cząstkowe i średnią całościową ocen, można byłoby stwierdzić, że w tym zakresie zasadnym byłoby $\mathrm{w}$ pierwszej kolejności wdrożenie działań związanych z poprawą czystości wewnątrz pojazdów. Następnie operator publicznego transportu zbiorowego w Częstochowie powinien skupić się na zapewnieniu bezpieczeństwa podróżnych w pojeździe, dostosowaniu pojazdów do potrzeb osób niepełnosprawnych oraz na modernizacji lub zakupie środków transportowych.

Uwzględniając kwestie podniesienia jakości taboru tramwajowego, przede wszystkim należałoby dostosować pojazdy do potrzeb osób niepełnosprawnych. Należy zauważyć, iż w tym przypadku oceny były najniższe ze wszystkich. Dalsze działania powinny zostać skupione kolejno na zapewnieniu czystości wewnątrz tramwajów, zagwarantowaniu bezpieczeństwa podróżnych wewnątrz pojazdu i poprawie stanu technicznego pojazdów. 


\section{Podsumowanie}

Podejmując rozważania dotyczące oceny jakości taboru komunikacji miejskiej w Częstochowie, autorka doszła do przekonania, iż osoby korzystające $\mathrm{z}$ autobusów i tramwajów oceniły ich jakość na poziomie dostatecznym. Srednia ocen wyniosła 3,61. Pozwala to na falsyfikację trzeciej hipotezy badawczej o brzmieniu: osoby korzystające z usług transportu zbiorowego w Częstochowie oceniają jakość autobusów miejskich i tramwajów na poziomie dostatecznym (średnia ważona ocen wynosi 4). Ponadto częstochowianie stwierdzili, że średnia ocena jakości autobusów realizujących przewozy drogowe w mieście jest lepsza od średniej oceny jakości tramwajów. Oznacza to, że wyniki przeprowadzonych badań własnych nie przeczą hipotezie drugiej o brzmieniu: użytkownicy infrastruktury komunikacji miejskiej lepiej oceniają jakość autobusów miejskich niż tramwajów.

W celu zwiększenia komfortu, wygody i bezpieczeństwa podróżowania organizator publicznego transportu zbiorowego $\mathrm{w}$ Częstochowie powinien w najbliższym czasie wprowadzić pewne ulepszenia. W przypadku autobusów miejskich należałoby priorytetowym uczynić działanie mające na celu utrzymanie czystości wewnątrz pojazdów. W tym przypadku można byłoby zwiększyć liczbę pracowników, których zadaniem będzie utrzymanie czystości taboru autobusowego. Istotną kwestią jest również zapewnienie bezpieczeństwa podróżnych. W tym wypadku należałoby skupić się na doposażeniu autobusów w kamery monitoringu czy wprowadzenie patroli policji (szczególnie w porze nocnej).

Rozpatrując kwestie podniesienia jakości taboru tramwajowego, priorytetem powinno stać się wdrożenie działań mających na celu dostosowanie środków transportu do potrzeb osób niepełnosprawnych. Obecnie na liniach komunikacji tramwajowej kursuje wiele pojazdów, które w żaden sposób nie są przystosowane do potrzeb osób poruszających się na wózkach inwalidzkich. W tym przypadku należałoby przede wszystkim skupić się na zainstalowaniu w tramwajach platform ułatwiających wprowadzenie wózka do tramwaju, przycisków (zarówno we wnętrzu, jak i na zewnątrz pojazdu), przy pomocy których można zasygnalizować potrzebę skorzystania z platformy. Kolejnym priorytetem, analogicznie jak w przypadku autobusów, powinno stać się utrzymanie w należytej czystości taboru tramwajowego.

Wyniki przeprowadzonych badań własnych pozwalają na falsyfikację trzeciej hipotezy badawczej, która została sformułowana w następujący sposób: utrzymanie w czystości autobusów i tramwajów pozwoliłoby w znacznym stopniu zwiększyć jakość taboru komunikacji miejskiej. O ile byłoby to możliwe w przypadku autobusów, to podniesienie jakości tramwajów może nastąpić na drodze lepszego ich dostosowania do potrzeb osób niepełnoprawnych.

Podsumowując, należy zauważyć, iż wyniki realizowanych przez autorkę badań pochodzą z roku 2016. Przez kolejny rok tabor autobusowy wzbogacił się o 43 nowoczesne pojazdy. Prawdopodobnie działanie to pozwoliło na podniesienie poziomu jakości taboru autobusowego w mieście. Stwierdzenie to staje się swoistą rekomendacją wskazującą kierunki przyszłych dociekań autorki. 


\section{Literatura}

Chłąd M., Jaroszyński J.W. (2015), Zarządzanie efektywnościa w jednostkach samorządu terytorialnego - gmina, „Zeszyty Naukowe Politechniki Częstochowskiej. Zarządzanie”, nr 20, s. 7-16.

Gołembska E. (2001), Kompendium wiedzy o logistyce, wyd. 2 poprawione i uzupełnione, Wydawnictwo Naukowe PWN, Warszawa.

Grondys K., Kott I., Sukiennik K. (2017), Funkcjonowanie polskich miast w dobie zrównoważonego rozwoju z punktu widzenia transportu, „Zeszyty Naukowe Politechniki Częstochowskiej. Zarządzanie", nr 25, t. 1, s. 237-245. DOI: 10.17512/znpcz.2017.1.1.21

Grzelec K., Wyszomirski O. (2002), Transport miejski w aglomeracji gdańskiej jako system logistyczny, „Logistyka”, nr 6, s. 24-27.

http://mzd.czest.pl/images/rozklady/mapka_si_kom.pdf (dostęp: 28.04.2017).

http://mzd.czest.pl/publiczny-transport-zbiorowy/rozklady-jazdy (dostęp: 28.04.2017).

http://silesiainfotransport.pl/?p=20274 (dostęp: 28.04.2017).

http://www.mpk.czest.pl/page/o-firmie/tabor (dostęp: 28.04.2017).

Janecki R., Krawiec S., Sierpiński G. (2010), Publiczny transport zbiorowy jako kluczowy element zrównoważonego systemu transportowego Górnoślasko-Zagłębiowskiej Metropolii Silesia, [w:] Pyka R. (red.), Sposób na Metropolię. Idee a społeczne oczekiwania wobec projektu utworzenia ślasko-zaglębiowskiej metropolii, UM Katowice, RSS MSNP UŚ, Katowice, s. 105-132.

Kabus J., Nowakowska-Grunt J. (2016), Uwarunkowania rozwoju lokalnego na przykładzie powiatu częstochowskiego, „Turystyka i Rozwój Regionalny”, nr 5, s. 39-47.

Kiciński M., Stasiak P. (2013), Ocena realizacji zakładanych zadań przewozowych na przykładzie przedsiębiorstwa publicznego transportu autobusowego ZUK Rokbus Sp. z o.o., „Autobusy: Technika, Eksploatacja, Systemy Transportowe”, nr 3, s. 555-564.

Kramarz M., Kramarz W., Bendkowski J. (2010), Metody i techniki ilościowe w logistyce stosowanej, Wydawnictwo Politechniki Śląskiej, Gliwice.

Krawczyk S. (2004), Logistyka w zarzadzaniu miastem, [w:] Nowakowski T. (red.), Logistyka a infrastruktura miejska. I Konferencja Naukowo-Techniczna, Wydawnictwo Consulting i Logistyka, Wrocław, s. 47-63.

Krawczyk S. (2011), Logistyka. Teoria i praktyka, Difin, Warszawa.

Krysiuk C. (2016), Przemiany infrastrukturalne miast - transport, „Transport Samochodowy", z. 1(51), s. 47-63.

Moterski F. (2008), Praktyczne wykorzystanie elementów logistyki w gospodarce miejskiej, [w:] Przygodzki Z., Sokołowicz M.E. (red.), Nowoczesne miasto. Badania, instrumenty, analizy, Wydawnictwo Uniwersytetu Łódzkiego, Łódź, s. 89-96.

Nowakowska-Grunt J., Chłąd M. (2015), Mobilność jako element zarzadzania miastem, „Zeszyty Naukowe Politechniki Częstochowskiej. Zarządzanie”, nr 20, s. 128-138.

Rzeczyński B. (2002), Logistyka miejska XXI wieku. Stowo odrębne z refleksja nad jej przeznaczeniem, „Logistyka”, nr 3, s. 8-11.

Rzeczyński B. (2004), Technologia i logistyka transportu a dynamika przestrzeni ekonomicznej miasta, „Logistyka”, nr 2, s. 13-15.

Skowron-Grabowska B. (2009), Dziatalność transportowo-magazynowa w procesach logistycznych. Materialy dydaktyczne, Sekcja Wydawnictw Wydziału Zarządzania Politechniki Częstochowskiej, Częstochowa.

Stajniak M. (2006), Transport w logistyce, [w:] Fertsch M. (red.), Podstawy logistyki. Podręcznik do ksztatcenia w zawodzie technik logistyk, Instytut Logistyki i Magazynowania, Poznań, s. 83-122. 
Stokłosa J., Rymarz J., Niewczas A. (2012), Czynniki wpływajace na funkcjonowanie transportu zbiorowego, „Autobusy: Technika, Eksploatacja, Systemy Transportowe”, nr 13, s. $152-156$.

Szołtysek J. (2005), Logistyczne aspekty zarzadzania przepływami osób i ładunków w miastach, Wydawnictwo Akademii Ekonomicznej, Katowice.

Szołtysek J. (2016), Logistyka miasta, PWE, Warszawa.

Taniguchi E., Thompson R.G., Yamada T. (1999), Modelling City Logistics, [w:] Taniguchi E., Thompson R.G. (eds.), City Logistics, Institute of Systems Science Research, Kyoto, s. 3-37.

Taniguchi E., Thompson R.G., Yamada T. (2013), Concepts and Visions for Urban Transport and Logistics Relating to Human Security, [w:] Taniguchi E., Thompson R.G., Yamada T. (eds.), Urban Transportation and Logistics: Health, Safety, and Security Concerns, CRC Press, Boca Raton, s. 1-30.

Tarski I. (1993), Ekonomika i organizacja transportu międzynarodowego, PWE, Warszawa. Urbanyi-Popiołek I. (red.) (2013), Ekonomiczne i organizacyjne aspekty transportu, Wydawnictwo Uczelniane Wyższej Szkoły Gospodarki w Bydgoszczy, Bydgoszcz.

Urząd Miasta Częstochowy (2013), Plan zrównoważonego rozwoju publicznego transportu zbiorowego dla Miasta Częstochowy, przygotowany przez Blue Ocean Business Consulting Sp. z o.o., s. 86-89, http://konsultacje.czestochowa.pl/?p=4198 (dostęp: 28.04.2017). Ustawa z dnia 16 grudnia 2010 r. o publicznym transporcie zbiorowym (Dz.U. 2011 nr 5 poz. 13, z późn. zm.).

Witkowski J. (2014), Pojęcie logistyki miejskiej i systemu logistycznego miasta, [w:] Kiba-Janiak M., Witkowski J. (red.), Modelowanie logistyki miejskiej, PWE, Warszawa, s. 11-16.

\title{
QUALITY ASSESSMENT OF A PUBLIC TRANSPORT FLEET ON THE EXAMPLE OF THE CITY OF CZĘSTOCHOWA
}

\begin{abstract}
In the article the author presents basic issues concerning organisation of regular carriage of people in public collective transport. The main aim of the article is to carry out evaluation of quality of the urban transport fleet in Częstochowa. A release of an opinion on that matter was possible owing to the research carried out by the author herself. First a currently used urban transport fleet is characterised, taking account of the number of vehicles, vehicle make, type and year of construction or purchase date. Such analysis could be conducted owing to the application of one of the qualitative research methods, namely the desk research method. On the other hand the quantitative resarch method (survey method) allowed to gather the residents' opinions on the author's queries, i.e. the condition of the urban transport vehicles (buses, trams), their adjustment to the needs of the disabled persons, cleanliness inside the vehicles or ensuring safety to users. The results of the research enabled to point priority actions which should be undertaken in order to improve the quality in that respect.
\end{abstract}

Keywords: public transport, communication line, communication network, fleet of public transport 